\title{
The Effect of Depreciation of the Exchange Rate on the Trade Balance of Albania
}

\section{Safet Kurtović ${ }^{1}$}

\begin{abstract}
Almost all countries face the problems of trade balance, although they are more inherent in developing countries and economies in transition. A majority of economists adheres to a common opinion real depreciation may lead to an improvement of the trade balance. That said, countries encountering trade balance issues use real exchange rate depreciation in order to improve the trade balance situation. Albania belongs to the group of transition countries that has been facing negative trade balance over last two decades. National currency devaluations of the lek (ALL) have been used by Albania to improve its trade balance. Therefore, this paper intends to investigate the effect of the real effective exchange rate depreciation of the ALL on the trade balance of Albania using quarterly data from 1994 to 2015. Bounds testing cointegration approach, vector error correction model (VECM) and impulse response were used for empirical analysis. The results of the study show that there exists a long-term cointegration between the real effective exchange rate depreciation and the trade balance. Specifically, real effective exchange rate depreciation positively affects the trade balance of Albania in both the long-run and short-run indicating the weak presence of the J-curve effect. Important recommendations were derived from the results.
\end{abstract}

Keywords: Cointegration, Elasticity, J-curve, Long-term effect, Short-term effect

JEL Classification: F14, F30, F31

Received: 19 October 2016/ Accepted: 7 February 2017 / Sent for Publication: 8 June 2017

\section{Introduction}

There is a strong argument among international trade economists that depreciation causes a decrease in trade balance deficit (Bahmani-Oskooee, 1985). The real exchange rate is an important macroeconomic measure underlying the adoption of certain economic policies. It indirectly affects the allocation of resources in the economy, i.e. traded and non-traded goods. An overvalued exchange rate is interpreted as a reduction or decline in price competitiveness, while an undervalued exchange rate is interpreted as a way towards a faster economic growth (Rodrik, 2008; Cakrani et al., 2013). Real exchange rate depreciation leads, in the short term, to a deterioration in the trade balance, while in the long term it leads to balance (Šimakova, 2013; Šimakova and

\footnotetext{
${ }^{1}$ Faculty of Management and Business Economics, University of Travnik, Aleja Konzula 5, 72270 Travnik, Bosnia and Herzegovina. E-mail: safetkurtovic71@yahoo.com

(C) 2017 by the authors; licensee Review of Economic Perspectives / Národohospodárský obzor, Masaryk University, Faculty of Economics and Administration, Brno, Czech Republic. This article is an open access article distributed under the terms and conditions of the Creative Commons Attribution 3.0 license, Attribution - Non Commercial - No Derivatives.
} 
Stavarek, 2015). Trade balance can be improved in two ways. The first is an internal approach and is based on the supply-side policies that improve productivity, reduce inflation and taxes and lead to a more efficient labor market. These measures leads to the growth of GDP and exports. Another way is currency depreciation which leads to changes in relative prices of imports and exports (Krueger, 1983; Stučka, 2004, Kurtovic et al., 2016).

The economic concepts of J-curve and depreciation of exchange rate are closely related. Magee (1973) was the first to introduce the concept of J-curve. Real exchange rate depreciation in the short term worsens the trade balance because the volume of imports remains stable, but more expensive due to a lower exchange rate. In the long run, there is an increase in exports and reduction in imports, leading to an improved trade, but not enough to achieve a surplus. The effect of depreciation leads to a decline in the prices of exports relative to imports (Khieu Van, 2013; Nagpal, in press; Sahlan et al., 2008; Kurtovic et al., 2016). Such a condition causes the trade balance to have a movement in the form of a curved J-curve (Magee, 1973; Bahmani-Oskooee and Kantipong, 2001; Bahmani-Oskooee and Goswami, 2003; Sorensen et al., 2010; Harvey, 2013, Kurtovic et al., 2016). After depreciation, there is the effect of a time lag in the trade balance. The time lag is a result of the slow recognition of resulting changes, making the right decisions, delivery delays, procurement of raw materials and the cost-effectiveness of continuing the process of production (Junz et al., 1973; Krugman and Baldwin, 1987; Bahmani-Oskooee, 1985; Kurtovic et al., 2016).

It is well known that numerous studies are trying to confirm the presence of the $\mathrm{J}$-curve, based on the traditional approach. The existence of the J-curve is confirmed by the following research of authors such as Spitaller (1980), Bahmani-Oskooee (1985), Krugman and Baldwin (1987), Demirden and Pastine (1995), Marwah and Klein (1996), Bahmani-Oskooee and Brooks (1999), Bahmani-Oskooee and Kantipong (2001), Willson (2001), Hacker and Hatemi-j (2003), Stučka (2004), Bahmani-Oskooee and Kutan (2006), Bahmani-Oskooee and Ratha (2007), Hsing (2008), Kalyoncu et al., (2009), Petrović i Gligorić (2010), Šimakova (2013; 2014). On the other hand, a slight or no presence of the J-curve was found by the following authors, such as Flemingham (1988), Rose and Yellen (1989), Demeulemeester and Rochat (1995), BahmaniOskooee and Goswami (2003), Yuen-Ling and Wai-Mun (2008).

Rose and Yellen (1989) investigated the effect of exchange rates on bilateral trade flows of the United States. The study used disaggregated quarterly data for the US and its six major trading partners from 1960 to 1985 . The results of the research did not show the presence of the J-curve. Hacker and Hatem-j (2003) investigated the presence of the Jcurve in the example of North-European economies. The study used econometric techniques, Johansen and Juselius maximum likelihood approach and vector error correction methods. The results showed presence of J-curve or a positive effect of real depreciation on the trade balance of the analyzed countries. Rincón (2004) investigated the effect of the real depreciation of exchange rate on the trade balance of Colombia. The study applied cointegration analysis and used monthly data from 1979 to 1995 . The results showed that depreciation has a positive effect in the long term on trade balance, reduces money supply and increases income. Stučka (2004) investigated the effect of the depreciation of exchange rate on the trade balance of Croatia. The study used quarterly data from 1994 to 2001 and applied the cointegration approach. The results 
showed the presence of the J-curve phenomenon. Bahmani-Oskooee and Kutan (2006) investigated the effect of depreciation on the trade balance of eleven countries of Central and Eastern Europe. The study used quarterly data from 1990 to 2005, and then applied cointegration approach and error-correction modeling. The results showed presence of J-curve in the cases of Russia, Croatia and Bulgaria. Vika (2006) investigated the response of exports and imports to the change of income, relative prices and exchange rate in Albania in the period from 1996 to 2005. The study used quarterly data and applied the vector error correction. The results showed that real income has dominant influence on trade flows, particularly on exports in the long term, while changes in prices have a greater impact on imports then the currency exchange rate. In addition, the study investigated the presence of Marshall-Lerner conditions and whether depreciation has a positive effect on reducing the trade deficit of Albania. Yuen-Ling and Wai-Mun (2008) investigated the effect of real depreciation on the trade balance of Malaysia in the period from 1955 to 2006. The study applied cointegration techniques, Vector Error Correction Model (VECM) and impulse response analyses. The results showed a positive effect of domestic income, foreign exchange rate on trade flows, but the presence of J-curve in the case of Malaysia has not been found.

Kalyoncu et al., (2009) investigated the effect of devaluation on the trade balance of four Latin American countries. The study applied the Johansen-Juselius cointegration test, generalized impulse response function and used the quarterly data from 1979 to 2005. The results showed that there is a positive effect of real devaluation on the trade balance of Argentina and Peru, i.e. a J-curve effect was recorded. However, in the cases of Brazil and Mexico, a positive effect has not been recorded. Petrović and Gligorić (2010) investigated the presence of the J-curve or the effect of depreciation on the trade balance of Serbia. The study applied the ARDL model and Johansen's approach Analysis. The results showed the presence of J-curve. Hoda (2013) investigated the effect of depreciation of exchange rates on trade balance of Albania. The study used quarterly data from 1998 to 2012 and applied the model of imperfect substitution and the Johansen approach. The results showed that income has a particular impact on trade flows, while the effect of the exchange rate is present in exports and has a significant impact on reducing the trade deficit. Šimakova (2013) investigated the effect of depreciation on the trade balance of Hungary with major trading partners. The study applied the Johansen's cointegration test and used the quarterly data from 1997 to 2012 . The results showed the presence of J-curve in the case of bilateral trade with the United Kingdom. Śimakova (2014) investigated the effect of depreciation on the trade balance of Slovakia in the process of bilateral trade with Poland, the Czech Republic and Hungary. The study used aggregate and disaggregate quarterly data from 1997 to 2013. In addition, the study applied the cointegration approach. The results showed the presence of the J-curve in the cases of Hungary and the Czech Republic.

The main objectives of this work are: 1) to investigate potential presence of cointegration variables; 2 ) to investigate whether there is a short-term effect and longterm effect of the real depreciation of the ALL on the trade balance of Albania, or whether there is the presence effect of the J-curve.

The paper consists of the sections as follows: The most significant papers are provided in Section 2; Section 3 contains databases used in the research and economic analysis; Section 4 presents the research results, while Section 5 gives conclusion. 


\section{Some Facts}

Albania belongs to the group of transition countries that has been facing negative trade balance over last two decades. National currency devaluations of the lek (ALL) have been used by Albania to improve its trade balance. After the fall of the communist regime in 1990, Albania was exposed to economic crisis, social unrest and enhanced migrations. Following these dangerous events, the Government of Albania adopted the reform agenda in 1992. The main objective of the reform agenda was to restrain galloping inflation from over 300\% to 20\% at the annual level (Muço et al., 2004; Cera et al., 2013). Albania introduced the floating exchange rate regime as the best solution to address the negative trade balance and current account deficit by automatic mechanism in the early stage of the transition and ensure capital inflows (Tanku et al., 2007). In the transitional period, both the monetary and exchange rate policy have remained unchanged, despite the changes caused by introduction of the euro in the European Monetary Union (EMU). Introduction of the euro has changed the relation to possession of currencies by economic operators. Thus, after 2000, the use of the euro for trade flows has grown in comparison to the US the of dollar (Muço et al., 2004).

Analyzing the period from 1994 to 2015, we may observe both devaluation and appreciation phase of the ALL. In the period from 1994 to 2003 the ALL devaluated against the US dollar and the euro. Underestimation of the ALL against the US dollar and the euro was caused by political instability, risk and inflation expectations. After 2003, the ALL appreciated to both currencies (the euro and the US dollar). That period was marked by the transformation of large trade deficit into rational current deficit amounting to $7 \%$ of the GDP. The current deficit could easily be covered by outward remittances and capital inflows from privatization resulting in an increase in foreign exchange reserves (Nuti, 2001; Agolli, 2004; Kola and Likko, 2008). However, in the period from 2004 to 2009 the ALL appreciated against the US dollar and it devalued against the US dollar in the period from 2011 to 2015. The devaluation of the ALL against the US dollar resulted in an improvement of the trade balance, but also in a mild increase of the current account deficit. On the other hand, the ALL appreciated against the euro in the period from 2004 to 2009. Afterwards (2010-2015) it devaluated against the euro. The average rate of the ALL against the US dollar amounted to 113,57 in the period from 1994 to 2015, while it amounted to 130,28 against the euro in the same period (see Figure 1).

Fluctuation in exchange rate of the ALL against the euro and the US dollar reflected also upon the Albanian's trade balance. Therefore, it is important to underline that Albania like other countries in South-East Europe recorded a negative trade balance in the period from 1994 to 2015. In the period from 1994 to 2002, devaluation of the ALL positively affected the Albanian trade balance. However, after 2003, the ALL appreciated, leading to deterioration of the trade balance. According to the data obtained by the Bank of Albania, fluctuation in the ALL remained balanced from the year 2000 onwards. The reasons for such a situation lay in overvaluation of the ALL against the US dollar and the euro during the whole period. The ALL was overvalued by $51 \%$ against the US dollar and by $19 \%$ against the euro in 2007. Current overvaluation of the ALL led to an improvement of the trade balance, balance of payments and foreign currency inflows (Kotorri and Korbi, 2009). A record trade deficit amounted to USD 3.891 billion in 2008. Finally, in the period from 2009 to 2015 , a trade balance 
improvement was recorded corresponding to the devaluation of the ALL against the US dollar (see Figure 2).

Figure 1: Exchange rate ALL vs Dollar/Euro

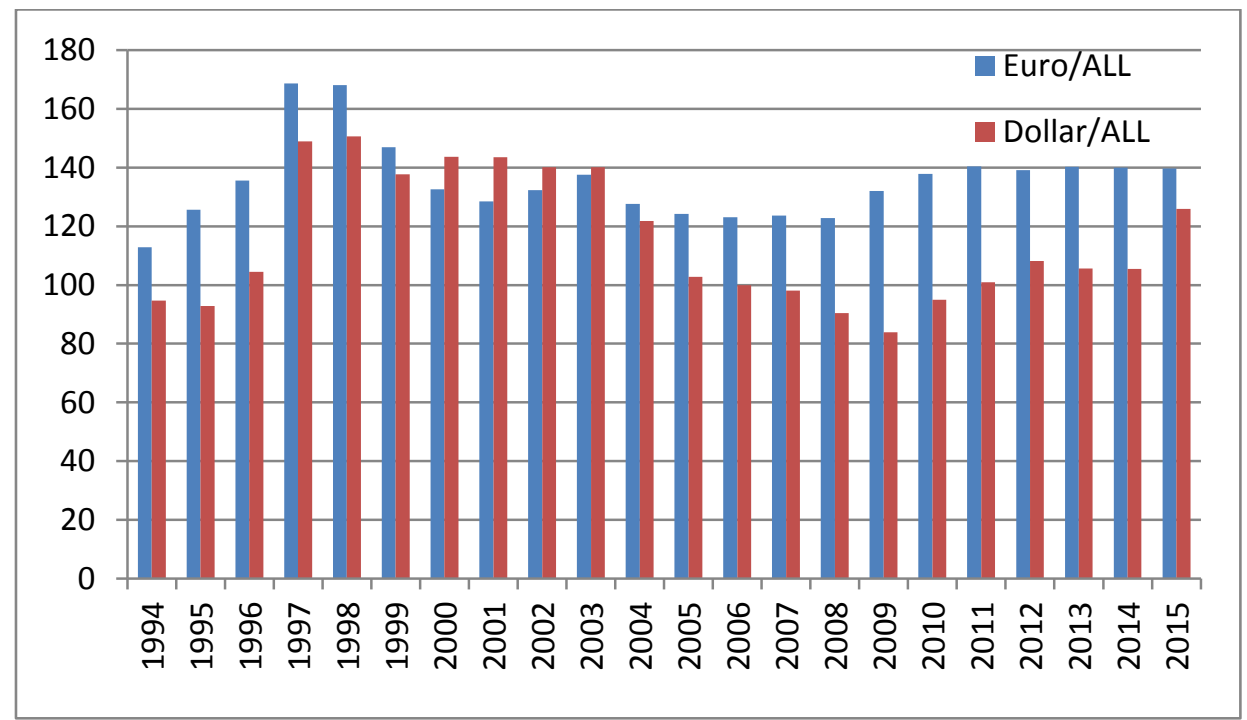

Note: The data were obtained from the Bank of Albania regarding exchange rate ALL $v r$ Dollar/Euro.

Source: Author's own compilation

Figure 2: Trade Balance of Albania

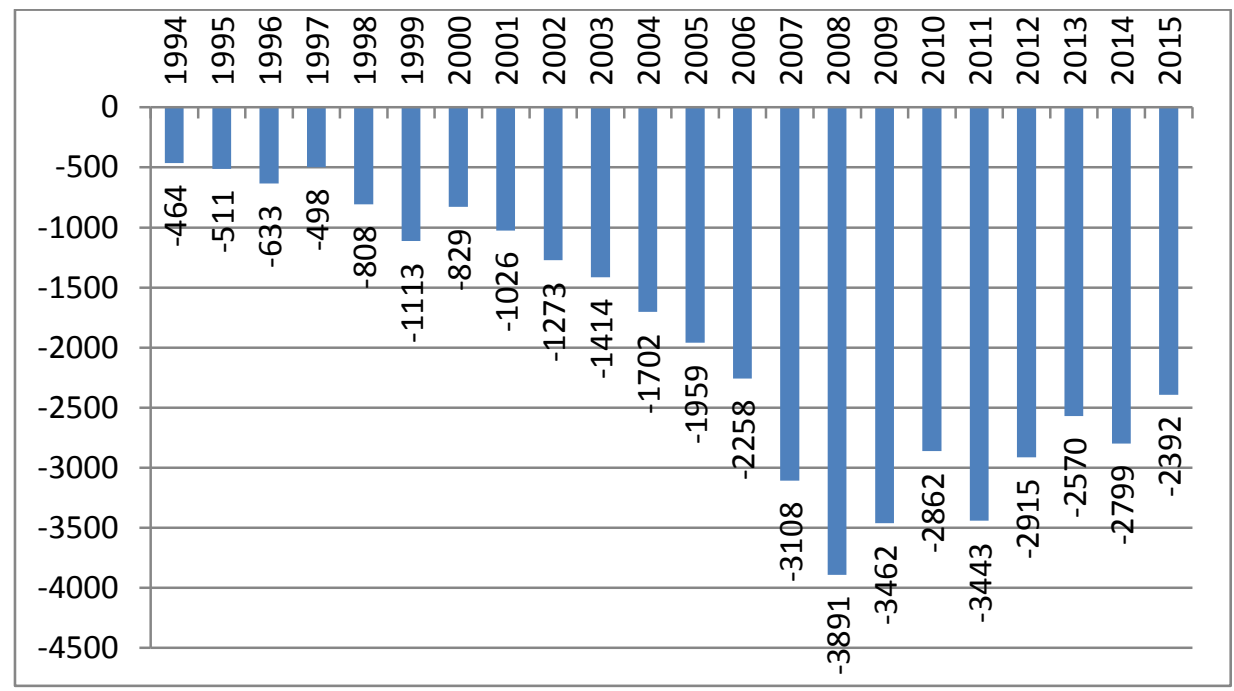

Note: Figure shows data obtained by the Eurostat and OECD.

Source: Author's own compilation 
In the end, it is important to emphasize that Albania's trade balance share to GDP amounted to record 27.6\% in 1994. In the period from 1995 to 2007, the trade balance significantly improved, i.e. exports were increased as compared to imports, positively affecting the trade balance share to the GDP. However, the second worst outcome pertaining to the trade balance share to the GDP was recorded in 2008 amounting to $26.85 \%$, after 1994. Trade balance share to the GDP improved significantly after 2009 amounting to $-17.72 \%$ in 2015 (see Figure 3).

Figure 3: Albanian Trade balance, percent of GDP

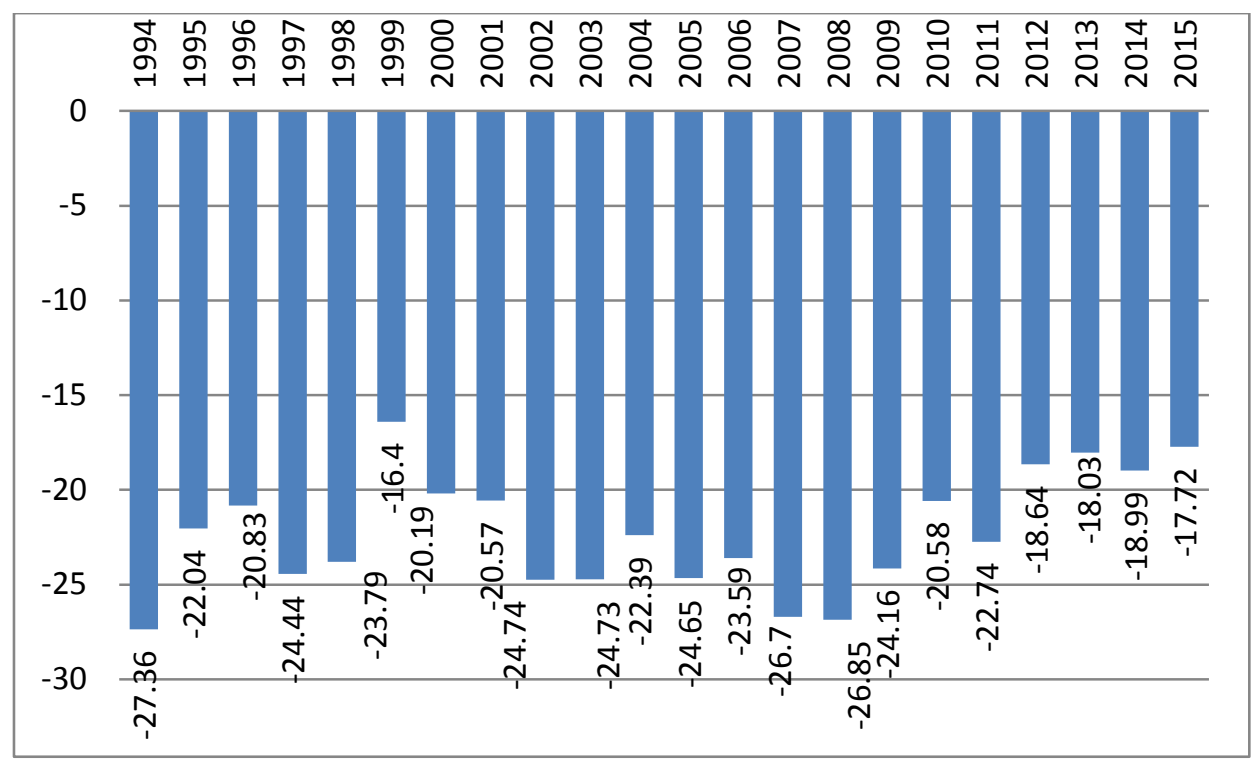

Note: Data was obtained by the World Bank.

Source: Author's own compilation

\section{Data and Methodology}

This research relates to the assessment of the effect of real depreciation of the real effective exchange rate (REER) on the trade balance of Albania. In the study we used the interpolated (non-seasonally adjusted) quarterly data 1994Q1 - 2015Q4. Data were taken from the following databases, such as Instat - Bank of Albania, World Bank (WDI), International Financial Statistics (IMF database) and Eurostat. The value of all variables is expressed in billions of dollars. Appendix to this research contains data resources and description of variables.

Evaluation of the trade elasticity is based on the imperfect substitute model that was developed by Goldstein and Kahn (1976) and Rose and Yellen (1989). The main assumptions of the model are as follows: a) domestically produced goods and imported goods are perfect substitutes; b) the model distinguishes between the domestic and the foreign country; c) each country produces a single good with a fixed price. 
The imperfect competition model consists of import and export demand functions for the domestic and the foreign country. The import demand function for the domestic country is given as follows:

$$
M_{d}=M_{d}\left(P_{m d}, Y\right)
$$

where $M_{d}$ represents the import demand function for the domestic country; $P_{m d}$ is the relative price of imported goods of the domestic home country; $Y$ is the real income of the domestic country. The import demand function for the foreign country is given as follows:

$$
M_{d}^{f}=M_{d}^{f}\left(P_{m f}^{f} Y^{f}\right)
$$

where $M_{d}^{f}$ represents the import of demand function for the foreign country; $P_{m f}^{f}$ is the relative price of imported goods of the foreign country; $Y$ stands for real income of the foreign country.

Once the import demand function for the domestic and the foreign country has been introduced, here is the export supply function of the domestic and the foreign country. The export supply function of the domestic country can be expressed as follows:

$$
X_{s}=X_{s}\left(P_{x d}\right)
$$

where $X_{s}$ represents the export supply function of the domestic country; $P_{m d}$ represents the relative price of the exported domestically produced goods. The export supply function of the foreign country can be expressed as follows:

$$
X_{s}^{f}=X_{s}^{f}\left(P_{x f}^{f}\right)
$$

where $X_{s}^{f}$ represents the export supply function of the foreign country; $P_{x f}^{f}$ denotes the relative price of the imported goods to the foreign country.

Based on the equations above, the relative import price of the domestic country can be defined as the coefficient of the domestically produced and foreign produced goods at home and abroad as argued by Hameed and Kanwal (2009):

$$
\left.P_{m d}=\frac{e P_{x}^{f}}{P}=\left(\frac{e P^{f}}{P}\right)\left(\frac{P_{x}^{f}}{P^{f}}\right)=\left(Q P_{x}^{f}\right) / P^{f}\right)=Q P_{x f}^{f}
$$

Whereby $e$ stands for the nominal exchange rate and $Q=e P^{f} / P$ denotes the real exchange rate. The relative import price of the foreign country is expressed as follows $P_{m f}^{f}=P_{x f} / Q$. Quantity of goods traded and their relative prices are determined by the following equilibrium conditions: $M_{d}=X_{s}^{f}$ and $M_{d}^{f}=X_{s}$. These conditions represent the equality between exports and imports of the domestic and the foreign country. Real income, price levels and exchange rates are considered exogenous. The trade balance of the domestic country is given as follows:

$$
T B=T B\left(Q, Y, Y^{f}\right)
$$

The real trade balance can be defined as a partial reduced form that depends on $Q, Y i Y^{f}$. Where $T B$ is the trade balance between the domestic country and its trading 
partners; $Q$ is the real exchange rate; $Y$ is the real income of the domestic country; $Y^{f}$ is the real income of the trading partners.

Equation (6) represents the basic equation for our analysis and it can be given as a loglinear form (Hameed and Kanwal 2009; Kurtovic et al., 2016):

$$
\operatorname{lnT} B_{i j, t}=\beta_{0}+\beta_{1} \ln R E E R_{i j, t}+\beta_{2} \ln G D P_{i, t}+\beta_{3} \ln G D P_{j, t}+e_{t}
$$

However, in our model, $G D P_{j, t}$, i.e. income of the trade partners was left out (see equation 8). Based on the research done by numerous authors, it has been determined that the income of developed trade partners $G D P_{j, t}$ does not have a positive effect on the trade balance of developing countries.

$$
\ln T B_{i j, t}=\beta_{0}+\beta_{1} \ln R E E R_{i j, t}+\beta_{2} \ln G D P_{i, t}+e_{t}
$$

Finally, we posed the null and the alternative hypothesis:

$H_{0}$ : Real exchange rate depreciation does not have a significant impact on improving the trade balance of Albania in both the short and long run $-H_{0}: u=0$.

$H_{1}$ : Real exchange rate depreciation has a significant impact on improving the trade balance of Albania in both the short and long run $-H_{0}: u \neq 0$.

The research is based on the application of the cointegration approach, better known as the Autoregressive Distributed Lag (ARDL). It is cointegration modelling which is widely accepted by researchers. The ARDL model was developed by Pesaran and Shin (1999) and Pesaran et al., (2001). The ARDL model has the following characteristics: the model is statistically more efficient in the process of determining cointegration relationships in small samples; the model can be applied when the regressors are not of the same order, or when the regressors are $\mathrm{I}(1)$ and/or $\mathrm{I}(0)$, i.e. it is not necessary to perform pre-testing for the existence of problems of the standard deviation; it is not necessary to operate a unit root test in the model, which means that it can be applied regardless of the fact of whether the regressors in the model are stationary, nonstationary or mutually cointegrated etc. (Pesaran et al., 2001; Pahlavani et al., 2005; Ketenci and Uz, 2011; Kurtovic et al., 2016).

The ARDL model requires the following two steps (Pesaran et al., 2001). The first step relates to the process of determining any significant long-term relationship between the variables using the F-test. The second step relates to the long-term relationship variables and determining their value, and assessment of the short-term elasticity of variables showing the error correction representation of the ARDL model. The result of the error correction model tells us about the speed of adjustment from the short-term shock to the long-term balance (Siddiqui et al., 2008; Kurtovic et al., 2016). The ARDL model is represented by the following equations:

$\Delta \ln T B_{i j, t}$

$$
\begin{aligned}
& =\beta_{0}+\beta_{1} t+\beta_{2} \Delta x_{t}+\sum_{i=1}^{m} \alpha_{1 i} \Delta \ln \Delta T B_{i j, t-1}+\sum_{i=0}^{m} \alpha_{2 i} \Delta \ln R E E R_{i j, t-1} \\
& +\sum_{i=0}^{m} \alpha_{3 i} \Delta \ln G D P_{i, t-1}+\lambda_{1} \Delta \ln T B_{i j, t-1}+\lambda_{2} \Delta \ln R E E R_{i j, t-1}+\lambda_{3} \Delta \ln G D P_{i, t-1}+e_{t}
\end{aligned}
$$


where $T B_{i j, t}$ measures the ratio of the trade balance between the domestic country and its trading partners; $R E E R_{i j, t}$ - Real Effective Exchange Rate based on the CPI. The Bank of Albania is directed at maintaining price stability so that CPI remains at $3 \%$ with a tolerance margin of $\pm 1 \%$. Furthermore, the Bank of Albania applies core/underlying inflation, traded and non-traded inflation and inflation expectations by economic operators to measure inflation and annual changes in the CPI (Mancheva, 2016). GDP $P_{i, t}$ is the real income of Albania; $\beta_{1} t$ and $\beta_{2} \Delta x_{t}$ represent the trend (first difference of current exogenous variables); $\alpha_{2}$ and $\alpha_{3}$ represent the short-term effect of the exchange rate and the domestic income on the trade balance; $\lambda_{2}$ and $\lambda_{3}$ represent the long-term effect of real depreciation of the exchange rate and the effect of income on the trade balance; $m$ represents the number of lags, $\beta_{0}$ represents drifts, $1 \mathrm{ln}$ - represents the natural logarithm, $e_{t}$ - represents the error term.

The steps in the bounds process are based on the F or Wald statistics and represent the first phase of ARDL cointegration method. The second phase relates to the F test of the null hypothesis of long-term variables with a time lag whose aggregate value equals zero, while in the case of the alternative hypothesis at least one long-term variable does not equal zero. This relationship is represented by the following relation (Bernstein and Madlener, 2011; Kurtovic et al., 2016):

Null Hypothesis or $H_{0}: \beta_{0}=\beta_{1}=\beta_{2}=0$ i.e. the long run relationship does not exist. Alternative Hypothesis or $H_{1}: \beta_{0} \neq \beta_{1} \neq \beta_{2} \neq 0$ i.e. the long run relationship exist.

Pesaran et al., (2001) calculated two levels of the critical value for the given level of significance. One level assumes that all variables are $\mathrm{I}(0)$, and the second level assumes that all the variables are I(1). In order to perform the specified testing, we will use the OLS model (9) with or without the linear trend and with and without $\Delta x_{t}$ (first difference of current exogenous variables). The length of lags is chosen based on the Akaike Information Criterion (AIC) and Schwarz Bayesian Criterion (SBC) (Petrović and Gligorić, 2010; Kurtovic et al., 2016).

Finally, diagnostic and stability tests are used to assess the reliability of ARDL models. The assessment of the diagnostic tests includes Lagrange Multiplier test, the Ramsey Reset test, the Jarque-Berra test and the KB test (Siddiqui et al., 2008; Kurtovic et al., 2016). Stability tests of variables are carried out by applying cumulative sum of squared recursive residuals, cumulative addition of recursive residuals (CUSUM), and cumulative sum of squared recursive residuals (CUSUMSQ) (Kurtovic et al., 2016).

Finally, we will apply the impulse response function based on the calculated ECM which allows the subsequent assessment of the trade balance for a certain period, i.e. the effect of real depreciation (Petrović and Gligorić, 2010). The impulse response function is defined as (Nguyen, 2011; Kurtovic et al., 2015):

$$
I R\left(m, h, Z_{t-1}\right)=E\left(\frac{y_{t+m}}{e_{t}}=h, Z_{t-1}\right)-E\left(y_{t+m} / e_{t}=Z_{t-1}\right)
$$


where $\mathrm{m}$ denotes time, $h=\left(h_{1}, \ldots, h_{m}\right)$ is $n \times 1$ vector denotes the size of a shock, the generalized impulse response function of $y_{t}$ at horizon $m Z_{t-1}$ denotes the accumulative information about economy from the past up to time $t-1$.

\section{Empirical Results}

Table 1 presents the results of the F-test or the Bond test. Based on the application of the F-test, we got the same number of lags for all variables, i.e. from 1 to 8 . The optimal number of lags is obtained based on the AIC or the SBC. For the relation $\beta_{1}=0$ and $\beta_{1} \neq 0$, i.e. according to the SBC and the AIC, the optimal number of lags is $m=6$. The value of the F statistics for 6 lags is 14.36 which is greater than the $1 \%$ value of the bound test 3.61, i.e. we can reject the null hypothesis and say there is a cointegration between the tested variables at the level of $1 \%$ of statistical significance.

Table 1: Results of the F-test

\begin{tabular}{|c|c|c|c|c|c|c|}
\hline \multirow{3}{*}{$\begin{array}{l}\mathrm{m}-\text { lag } \\
\text { length }\end{array}$} & \multicolumn{3}{|c|}{$\beta_{1}=0$} & & \multicolumn{2}{|c|}{$\beta_{1} \neq 0$} \\
\hline & \multicolumn{6}{|c|}{$\beta_{2}=0$} \\
\hline & AIC & SC & F-stat & AIC & $\mathrm{SC}$ & F-stat \\
\hline 1 & -0.93 & -1.13 & $17.01(1)$ & -1.40 & -1.54 & $11.21(1)$ \\
\hline 2 & -0.98 & -1.23 & $16.96(1)$ & -1.39 & -1.59 & $4.94(1)$ \\
\hline 3 & -1.01 & -1.32 & $15.56(1)$ & -1.34 & -160 & $6.73(1)$ \\
\hline 4 & -1.04 & -1.41 & $15.81(1)$ & -1.38 & -1.70 & $6.74(1)$ \\
\hline 5 & -1.06 & -1.50 & $14.66(1)$ & -1.33 & -1.71 & $8.25(1)$ \\
\hline 6 & -1.10 & -1.60 & $14.36(1)$ & -1.37 & -1.81 & $8.33(1)$ \\
\hline 7 & -0.72 & -1.28 & $12.69(1)$ & -1.12 & -1.62 & $11.40(1)$ \\
\hline 8 & -0.74 & -1.37 & $16.47(1)$ & -1.15 & -1.71 & $6.91(1)$ \\
\hline \multicolumn{7}{|c|}{$\beta_{2} \neq 0$} \\
\hline 1 & -1.10 & -1.30 & $8.20(1)$ & -1.11 & -1.28 & $14.96(1)$ \\
\hline 2 & -1.15 & -1.40 & $5.66(1)$ & -1.17 & -1.39 & 13.49 (1) \\
\hline 3 & -1.15 & -1.47 & $5.37(1)$ & -1.14 & -1.42 & $14.53(1)$ \\
\hline 4 & -1.18 & -1.55 & $5.68(1)$ & -1.17 & -1.51 & 14.94 (1) \\
\hline 5 & -1.18 & -1.61 & $5.79(1)$ & -1.16 & -1.57 & $14.98(1)$ \\
\hline 6 & -1.20 & -1.70 & $6.39(1)$ & -1.18 & -1.65 & $15.48(1)$ \\
\hline 7 & -0.79 & -1.35 & $11.11(1)$ & -0.76 & -1.29 & $14.02(1)$ \\
\hline 8 & -0.83 & -1.45 & $9.44(1)$ & -0.80 & -1.40 & $18.83(1)$ \\
\hline
\end{tabular}

Notes: The relevant critical value bounds for F-statistics are taken from tables CI. iii case III in Pesaran et al., (2001).Unrestricted intercept and no trend (2.45-3.61) at 0,5\% significance level, (3.15-4.33) at 0,1\% significance level.

Source: Author's own compilation 
Identical results were obtained in the cases of relations $\beta_{1} \neq 0$ and $\beta_{2}=0$, i.e. the optimal number of lags is at the level 1 and 6 , and the $F$ value is 11.21 and 8.33, which is greater than $1 \%$ of value of the bound test 4.33 . On the basis of the given parameters we reject the null hypothesis and accept the alternative hypothesis that there is a cointegration between the variables at the level of $1 \%$ of statistical significance. For the relations $\beta_{1}=0$ and $\beta_{2} \neq 0$ and $\beta_{1} \neq 0$ and $\beta_{2} \neq 0$ the optimal number of lags is at the second and sixth level. In all cases, the $F$ statistics is greater than the bond statistics which confirms the presence of cointegration. In the end, the values of the coefficients show that there is no trend.

After we investigated the presence of cointegration, our research is further directed towards the assessment of cointegration vectors. For the calculation of the cointegration vector, we again use model 8 , on the basis of which we estimate the optimal number of lags for each variable. Based on the SBC and the AIC criteria, we assess for the relations $\beta_{1}=0$ and $\beta_{1} \neq 0$ and $\beta_{1}=0$ and $\beta_{2} \neq 0$ the optimal number of lags obtained by the ARDL model $(1,6,6)$ - represented in Table 2 . The assessed ARDL $(1,6,6)$ model in Table 2 gives the following cointegration coefficients (with $t$ coefficient in parenthesis): $\lambda 1=-0.47(-3.48), \lambda 2=-1.98(-5.19), \lambda 3=0.76(5.00)$. Then we got the long-term equation of trade balance by renormalization of the obtained cointegration vector, i.e. dividing by $\lambda 1(-0.47)$.

$$
\ln T B_{i j, t}=4.2 \ln R E E R_{i j, t}-1.62 \ln G D P_{i, t}
$$

Table 2: ARDAL (1,6,6) - long-term cointegration

\begin{tabular}{|l|c|c|c|}
\hline \multicolumn{1}{|c|}{ Variable } & & Coefficients & t-stat \\
\hline TBt-1 & & -0.47 & -3.48 \\
\hline REERt-1 & & -1.98 & -5.19 \\
\hline GDPt-1 & & 0.76 & 5.00 \\
\hline$\Delta R E E R_{t-1}$ & & -2.31 & -6.08 \\
\hline$\Delta R E E R_{t-2}$ & & -2.30 & -5.60 \\
\hline$\Delta R E E R_{t-3}$ & & -2.18 & -5.50 \\
\hline$\Delta R E E R_{t-4}$ & & -2.11 & -5.32 \\
\hline$\Delta R E E R_{t-5}$ & 0.647643 & -2.03 & -5.16 \\
\hline$R^{2}$ & 0.567562 & & \\
\hline Adj $R^{2}$ & 32.54643 & & \\
\hline Log Likelihood & 0.609973 & & \\
\hline S.D. dependent var & 1.859333 & & \\
\hline Durbin-Watson stat & 1.184059 & & \\
\hline Akaike info criterion & 1.653663 & & \\
\hline Schwarz criterion & & & \\
\hline Source: $A$ ints & & & \\
\hline
\end{tabular}

Source: Author's own compilation

Based on the resulting cointegration equation, ARDL $(1,6,6)$ model shows the positive impact of real depreciation and income on the trade balance. Long-term real depreciation leads to an improvement of the trade balance, while, on the other hand, 
long-term appreciation leads to a deterioration in the trade balance. The estimated or calculated elasticity is $4.2 \%$, which indicates that the real depreciation of $1 \%$ causes an improvement of $4.2 \%$ in the trade balance (see equation 11). In addition, based on the equation of trade balance, the growth of domestic income or the GDP leads to an improvement of the trade balance. The estimated elasticity of GDP is $1.62 \%$. These results suggest that a $1 \%$ increase in domestic income or $G D P_{i, t}$ would account for a $1.62 \%$ increase in Albanian trade balance. The growth of domestic income occurred as a result of the growth in domestic production and exports, i.e. the growth of foreign demand. The GDP growth of Albania from 1997 to 1999 experienced the largest decline as a result of political unrest that occurred then, to grow in the coming years, or more precisely to 2008. After 2008, the GDP significantly fell as a result of the global economic crisis and post-crisis cyclical years.

Table 3: ECM for Trade Balance on ARDL $(1,6,6)$ model - short-term effect

\begin{tabular}{|l|c|c|c|}
\hline \multicolumn{1}{|c|}{ Variable } & & Coefficients & t-stat \\
\hline$\Delta R E E R_{t-1}$ & & -0.66 & -0.49 \\
\hline$\Delta R E E R_{t-2}$ & & 2.06 & 1.79 \\
\hline$\Delta R E E R_{t-3}$ & & 2.36 & 2.04 \\
\hline$\Delta R E E R_{t-4}$ & & 2.98 & 2.25 \\
\hline$\Delta R E E R_{t-5}$ & & 4.50 & 3.69 \\
\hline$\Delta R E E R_{t-6}$ & & 2.36 & 1.96 \\
\hline $\boldsymbol{E} \boldsymbol{C}_{t-1}$ & & -0.33 & -2.99 \\
\hline$R^{2}$ & 0.673347 & & \\
\hline Adj $R^{2}$ & 0.597965 & & \\
\hline Log Likelihood & -28.70588 & & \\
\hline S.D. dependent var & 0.607195 & & \\
\hline Durbin-Watson stat & 2.020519 & & \\
\hline Akaike info criterion & 1.103849 & & \\
\hline Schwarz criterion & 1.576827 & & \\
\hline LM & 0.94 & & \\
\hline RESET & 0.76 & & \\
\hline Normality & 0.28 & & \\
\hline CUSUM & stable & & \\
\hline CUSUM of squares test & stable & & \\
\hline Sowrc: sut & & & \\
\hline
\end{tabular}

Source: Author's own compilation

Table 3 presents the results of coefficients based on the introduction of error correction model (the coefficients of $E C_{(t-1)}$ of the error-correction model). ECM model serves to the show short-term effect of real depreciation of exchange rate on the trade balance. $E C_{(t-1)}$ is obtained on the basis of equation 8 and the results of the coefficients are represented in Table 3. Based on the values of the coefficients, a weak effect of the Jcurve has been observed, which assumes that the coefficients of exchange rate are negatively significant in shorter time lags, and positively significant in longer time lags. Thus, in the first quarter we have a negative insignificant value of -0.66 , while in other quarters the value is positive and significant. The calculated value $E C_{(t-1)}$ for REER is negatively significant, i.e. the value of the coefficient is -0.33 and the t-statistics -2.99 
(see Table 3). The negative value $E C_{(-1)}$ shows a direct deterioration of the trade balance after depreciation, whereas the effect of appreciation has a reverse effect. $E C_{(t-1)}$ tells us about the speed of the equilibrium adjustment which is $33 \%$, which means that the imbalance of the trade balance is corrected in less than a year. In shortrun, real depreciation affects the deterioration of the trade balance, while in the long-run it affects the improvement of the trade balance. In addition, Table 3 presents the diagnostic statistics. LM test tells us that there is no autocorrelation in the disturbance of the error term. Jarque-Bera normality test shows us that the model errors are normally distributed. The RESET test tells us that the models are correctly specified. In the case of CUSUM and CUSUMSQ tests, the stability of our model is confirmed.

The impulse response function is obtained on the basis of ECM and provides the ability to assess the evolution of the trade balance subsequently after real depreciation. The results are presented in Figure 4, and show that the trade balance worsened in the first ten quarters after real depreciation, and that it only improved and reached a new equilibrium value in the $11^{\text {th }}$ quarter. On the other hand, deterioration in the trade balance led to devaluation of the real exchange rate, and, consequently to an appreciation. The results of the impulse response show a weak presence effect of the Jcurve in the relationship between the depreciation of the real effective exchange rate and the trade balance of Albania.

\section{Figure 4: The reaction of the trade balance on real depreciation}
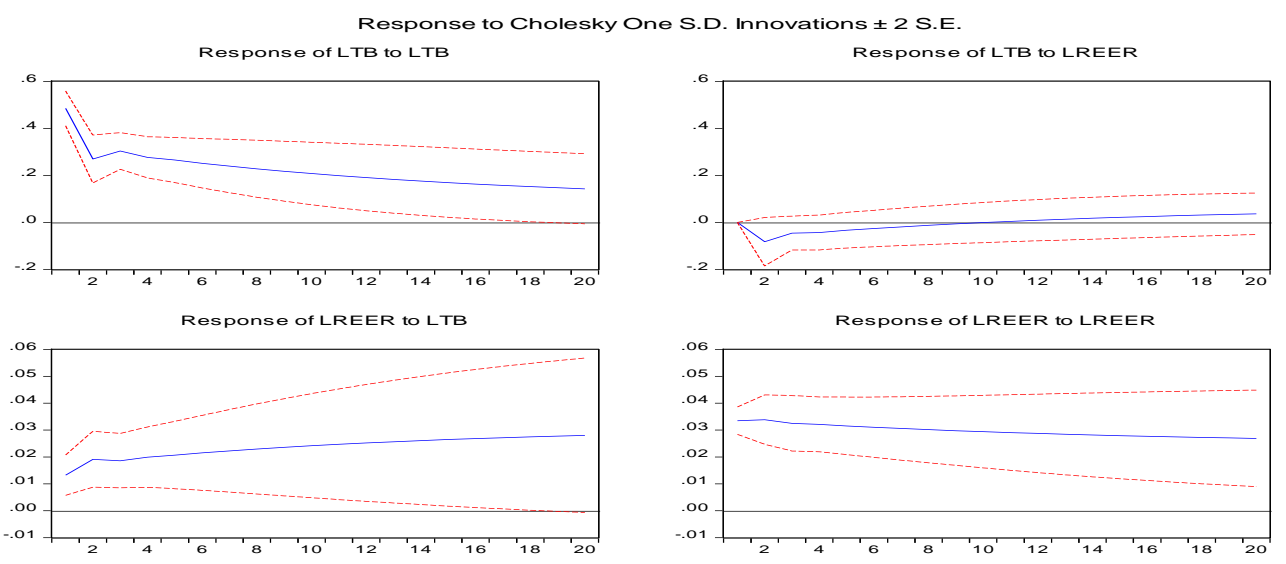

Source: Author's own compilation

\section{Conclusions}

The results of this study showed the presence of the short-term and the long-term effect of real depreciation of the exchange rate on the trade balance of Albania. The results showed that the GDP of Albania has a positive effect on the trade balance in the long term. In addition, using vector error-correction model, or ECM, we explored the positive effect of real depreciation on the trade balance in the short run, i.e. a weak presence effect of J-curve. ECM model showed that real depreciation has a negative effect on the trade balance in the first quarter, followed by an improvement in the following quarters. Along these lines, we applied the impulse response of the trade 
balance to real depreciation. The result showed a weak presence effect of J-curve, calculated on the basis of ECM and unrestricted VAR model, i.e. the trade balance worsened in the first quarter to gradually improve in the following quarters, and to achieve balance only in the eleventh quarter.

It is evident that the real exchange rate depreciation can improve the trade balance in the long run. However, the use of depreciation can not be significantly effective without the use of appropriate macroeconomic policies. When combined, real depreciation and macroeconomic policies can improve the competitiveness of an economy, i.e. export activity.

Acknowledgments: I would like to thank Ilir Vika and reviewers for helpful comments.

Disclosure statement: No potential conflict of interest was reported by the author.

\section{References}

AGOLLI, M. (2004) Exchange Rate Volatility Effect on Trade variations. Retrieved April 13, 2016 from http://pdc.ceu.hu/archive/00002085/01/may_2004_MAgolli.pdf

BAHMANI-OSKOOEE, M. (1985) Devaluation and the J-Curve: Some Evidence from LDCs. The Review of Economics and Statistics, 67 (3), pp. 500-504. DOI.org/10.2307/1925980

BAHMANI-OSKOOEE, M., KANTIPONG, T. (2001) Bilateral J-Curve Between Thailand and Her Trading Partners. Journal of Economic Development, 26 (2), pp.107117.

BAHMANI-OSKOOEE, M., GOSWAMI, G. G. (2003) A Disaggregated Approach to Test the J-Curve Phenomenon: Japan versus Her Major Trading Partners. Journal of Economics and Finance, 27 (1), pp. 102-113.

BAHMANI-OSKOOEE, M., BROOKS, T. J. (1999) Bilateral J-curve between US and her trading partners.Weltwirtschaftliches Arch, No. 135, pp. 156-165. DOI.org/10.1007/BF02708163

BAHMANI-OSKOOEE, M., KUTAN, M. A. (2006) The J-Curve in the Emerging Economies of Eastern Europe. EMG Working Paper Series WP-EMG-01-2006.

BAHMANI-OSKOOEE, M. AND RATHA, A. (2007) The Bilateral J-Curve: Sweden versus her 17 Major Trading Partners. International Journal of Applied Economics, 4 (1), pp. 1-13.

BERNSTEIN, R., MADLENER, R. (2011) Residential Natural Gas Demand Elasticities in OECD Countries: An ARDL Bounds Testing Approach. FCN Working Paper No. 15.

CAKRANI, E., RESULAJ, P., KOPRENCKA, L. K. (2013) Government Spending and Real Exchange Rate Case of Albania. European Journal of Sustainable Development, 2 (4), pp. 303-310.

CERA, G., CERA, E., LITO, G. (2013) A Garch Model Approach to Calculate the Value at Risk of Albanian Lek Exchange Rate. European Scientific Journal, 9 (25), pp. 250-260. 
DEMEULEMEESTER, J. L., ROCHAT, D. (1995) An Empirical Investigation of the Relationship between the Exchange Value of the Pound and the UK Trade balance. Economia Internazionale, 48 (3), pp. 347-357.

DEMIRDEN, T., PASTINE, I. (1995) Flexible exchange rates and the J-curve: An alternative approach. Economics Letters, No. 48, pp. 373-7. DOI.org/10.1016/01651765(94)00634-E

FLEMINGHAM, B. S. (1988) Where is the Australian J-curve?. Bulletin of Economic Research, 40(1), pp. 43-56. DOI.org/10.1111/j.1467-8586.1988.tb00253

GOLDSTEIN, M., KHAN, M. S. (1976) Large versus small price changes and the demand for imports. IMF Staff Papers, No. 23, pp. 200-225. DOI.org/10.2307/3866671

HAMEED, A., KANWAL, S. (2009) Existence of a J-Curve-The Case of Pakistan. Journal of Economic Cooperation and Development, 30(2), pp. 75-98. Retrieved February 14, 2017 from http://library.sesrtcic.org/files/article/309.pdf

HARVEY, H. (2013) Exchange rate sensitivity in the Philippines: Does the J-curve exist? Asian Journal of Business and Management Sciences, 2 (10), pp. 51-61.

HODA, B. (2013) The Role of Exchange Rates in International Trade Models: Does the Marshall-Lerner Condition Hold in Albania?. Working Paper 13(52).

HSING, Y. (2008) A Study of the J-Curve for Seven Selected Latin American Countries. Global Economy Journal, 8(4), pp. 1-12. DOI.org/10.2202/1524-5861.1438

JUNZ, H., RHOMBERG, R. R. (1973) Price Competitiveness in Export Trade among Industrial Countries. American Economic Review, No. 63, pp. 412-418.

KALYONCU, H., OZTURK, I., ARTAN, S., KALYONCU, K. (2009) Devaluation and trade balance in Latin American countries. Zbornik radova Ekonomskog fakulteta Rijeka, 27 (1), pp. 115-128.

KETENCI, N., UZ, U. (2011) Bilateral and regional trade elasticities of the EU. Empirical Economics, No. 40, pp. 839-854. DOI.org/10.1007/s00181-010-0365-8

KHIEU VAN, H. (2013) The effects of the real exchange rate on the trade balance: Is there a J-curve for Vietnam? A VAR approach. MPRA Paper No. 54490.

KOTORRI, A., KORBI, A. (2009) Can a South East European Country Have a Strong Currency? Albania Case. WSpótczesna Ekonomia, Nr.1/(9), pp. 43-52. Retrieved February 12, 2017 from https://doaj.org/article/22a48da51332488eaf1fd29e8fa5b0e9

KOLA, T., LIKKO, E. (2008) An Empirical Assessment of Alternative Exchange Rate Regimes in Medium Term in Albania. BERG Working paper series on government and growth No. 58.

KRUEGER, O. A. (1983) Exchange Rate Determination. Cambridge: Cambridge University Press.

KRUGMAN, P., BALDWIN, E. R. (1987) The Persistence of the US Trade Deficit. Brookings Papers on Economic Activity, No.1-2, pp. 1-43. DOI.org/10.2307/2534513 
KURTOVIC, S. HALILI, B., MAXHUNI, N. (2016) Bilateral Trade Elasticity: B\&H versus its seven trade partners. MPRA Paper No. 72297.

KURTOVIC, S., TALOVIC, S., DACIC, L. (2015) Foreign Direct Investment and Net Wages: The Case of Western Balkan Countries. British Journal of Economics, Finance and Management Sciences, 10(2), pp. 130-156.

MANCHEVA, G. (2016) Monetary Policy in Albania 2006-2015. Economic Alternatives, No. 4, pp. 461-474. Retrieved February 10, 2017 from http://www.unwe.bg/uploads/Alternatives/G_M_2016_Issue4_en-6.pdf

MAGEE, P. S. (1973) Currency Contracts, Pass-through, and Devaluation. Brookings Papers on Economic Activity, 4(1), pp. 303-325. DOI.org/10.2307/2534091

MARWAH, K., KLEIN, L. R. (1996) Estimation of J-curves: United States and Canada. Canadian Journal of Economics, No. 29, pp. 523-540. doi.org/10.2307/136248

MUÇO, M., SANFEY, P., TACI, A. (2004) Inflation, exchange rates and the role of monetary policy in Albania. Working paper No. 88.

NAGPAL, M. (In press) The JCurve Phenomenon: Myth or Reality? - An Analysis for India. Retrieved March 6, 2016 from https://www.econ-jobs.com/research/18594-The-JCurve-Phenomenon--Myth-or-Reality-.pdf

NGUYEN, T. H. (2011) Exports, Imports, FDI and Economic Growth. Working Paper No. 11-03.

NUTI, M. D. (2001) Albania and Euro. Paper was presented at the Albania Between Domestic Reforms and Europian Integration, Second Conference of the Bank of Albania. Tirana, Albania, December 6 - 7 .

OECD (2002) Use of Benchmarkt Data to Align or Derive Quarterly/Monthly Estimates. Retrieved February 9, 2017 from http://www.oecd.org/std/fin-stats/1933614.doc

PAHLAVANI, M., WILSON, E., WORTHINGTON, A. C. (2005) Trade-GDP Nexus in Iran: An Application of the Autoregressive Distributed Lag (ARDL) Model. American Journal of Applied Sciences, 2(7), pp. 1158-1165. DOI.org/10.3844/ajassp.2005.1158.1165

PESARAN, H. M., SHIN, Y., SMITH, R. J. (1999) Bounds Testing Approaches to the Analysis of Long-Run Relationships. Discussion Paper Series, No. 46.

PESARAN, M. H., SHIN, Y., SMITH, R. J. (2001) Bounds Testing Approaches to the Analysis of Long-Run Relationships. Journal of Applied Econometrics, 16 (3), pp. 289326. DOI.org/10.1002/jae.616

PETROVIĆ, P., GLIGORIĆ, M. (2010) Exchange Rate and Trade Balance: J-curve Effect, Panoeconomicus, No.1, pp. 23-41. DOI.org/10.2298/PAN1001023P

RINCÓN, C. H. (2004) Testing the Short-and-Long-Run Exchange Rate Effects on Trade Balance: The Case of Colombia, Retrieved March 19, 2016 from http://www.banrep.gov.co/docum/ftp/borra120.pdf

RODRIK, D. (2008) The Real Exchange Rate and Economic Growth. Retrieved May 19, 2016 from http://online.wsj.com/public/resources/documents/rodrick.pdf 
ROSE, A., YELLEN, L. J. (1989) Is There a J-curve?. Journal of Monetary economics, No. 24, pp. 53-68. DOI.org/10.1016/0304-3932(89)90016-0

SAHLAN, R., ABDULL, H., BOSS ABDULLAH, R. M. (2008)Trade Balance and JCurve Phenomenon in Malaysia. Journal Ekonomi Malaysia, No. 42, pp. 91-104.

SIDDIQUI, S., ZEHRA, S., et al. (2008) Export-Led Growth Hypothesis in Pakistan: A Reinvestigation Using the Bounds Test. The Lahore Journal of Economics, 13 (2), pp. 59-80.

SORENSEN, E. B. (1997) In Economics 266. Retrieved Mary 9, 2016 from http://www.uh.edu/ bsorense/coint.pdf

SPITALLER, E. (1980) Short-run Effects of Exchange Rate Changes on Terms of Trade and Trade Balance. IMF Staff Papers, No. 27, pp. 320-348. DOI.org/10.2307/3866715

STUČKA, T. (2004) The Effects of Exchange Rate Change on the Trade Balance in Croatia. IMF Working Paper 04/65.

TANKU, A., VIKA, I., GJERMENI, M. (2007) The Role of Exchange Rate in an IT Framework, What do We Do?, Bank of Albania. Retrieved February 12, 2017 from https://www.bankofalbania.org/web/The_Role_of_Exchange_Rate_in_an_IT_Framewo rk_What_do_we_do_5392_2.php?kc=0,22,11,10,0

ŠIMAKOVA, J. (2013) Estimation of the J-curve effect in the bilateral trade of Hungary. Ekonomická revue - Central European Review of Economic, No. 16, pp. 183191.

ŠIMAKOVA, J. (2014) The Effects of Exchange Rate Change on the Trade Balance of Slovakia. European Financial and Accounting Journal, 9(3), pp. 50-56.

ŠIMAKOVA, J., STAVAREK, D. (2015) The Effect of the Exchange Rate on IndustryLevel Trade Flows in Czechia. E+M Ekonomie a Management, 8(4), pp. 150-165. DOI.org/10.15240/tul/001/2015-4-011

VIKA, I. (2006) Measuring import and export functions in Albania. Retrieved March 28 , 2016 from https://www.bankofalbania.org/previewdoc.php?crd=5347\&ln=2\&uni=2009031915261 11901-a

WILLSON, P. (2001) Exchange rates and the trade balance for dynamic Asian economies: Does the J-curve exist for Singapore, Malaysia and Korea. Open Economies Review, No. 12, pp. 389-413. DOI.org/10.1023/A:1017982901034

YUEN-LING, N., WAI-MUN, H. (2008) Real Exchange Rate and Trade Balance Relationship: An Empirical Study on Malaysia. International Journal of Business and Management, 3(8), pp.130-137. 


\section{Appendix}

\section{Data sources and description}

It refers to the interpolated (no seasonally adjusted) quarterly data 1994Q1 - 2015Q4 taken from the following databases:
a) International Financial Statistics of IMF (CD-ROM).
b) Eurostat - Database
c) OECD - data
d) Instat - Bank of Albania

\section{Variables}

$T B_{i j t}$ - measures the ratio of trade balance between the domestic country and trading partners (data was taken from sources: $\mathrm{b}, \mathrm{c}$ ).

$R E E R_{i j t}$ - Real Effective Exchange Rate based on CPI. The real effective exchange rate (REER) on CPI is the weighted average of the ALL relative to an index or basket of other six major currencies, adjusted for the effect of inflation. The weights are determined by comparing the relative trade balance of a country's currency against each country within the index (data was taken from source d).

$G D P_{i, t}$ - is the real income of Albania. Income of an individual, organization, or country, after taking into consideration the effects of inflation on purchasing power (data was taken from sources b, d). 